\title{
COMPARATIVE STUDY AMONG IRRIGATION SYSTEMS FOR COWPEA YIELD IN SANDY SOIL
}

\author{
Abdel- Aal E. I. * M. A. Hassan**
}

\begin{abstract}
A field study was conducted at the experimental Farm of the Faculty of Agriculture, Zagazig Univeristy, Sharkia Governorate, during the summer season 2009 to determine comparative study between irrigation systems (traditional, sprinkler, drip and subsurface) for irrigation efficincy, water saving, cowpea yield, yield components, water use efficincy and net profit in sandy soil conditions.
\end{abstract}

The experimental results reveal that:

- The application efficiency; distribution uniformity and irrigation efficiency for subsurface irrigation increased by 4.2, 13.5 and 60.1\%; 4.57, 15.97 and 29.06\% and 8.99, 31.70 and 109.75\% compared with drip, sprinkler and traditional systems.

- $K c_{\text {calculated }}$ and $K c_{F A O}$ values were 0.40 and $0.41 ; 0.82$ and 1.05 and 0.55 and 0.60 at the different stage of cowpea.

- Drip system increased the pod yield and WUE by 14.98 and 9.47\%, 40.42 and $57.58 \%$ and 61.76 and $188.89 \%$ compared with subsurface, sprinkler and traditional systems.

- The highest water saving was obtained of 1780,1675 and $1420 \mathrm{~m}^{3} / \mathrm{fed}$ under subsurface, drip and sprinkler compared with traditional systems.

- $\quad$ The highest net profit was obtained of 3276, 2680, 1823 and 1602 LE/fed under drip, subsurface, traditional and sprinkler irrigation systems.

Keywords: irrigation systems, water saving, efficiency, net profit, cowpea.

\section{INTRODUCTION}

$\int$ r rrigation systems is considered one of the important limiting factors affecting the agricultural production. Sandy soils are generally characterized as very poor for moisture holding capacity and scarcity of organic matter. Cowpea is a summer vegetable legume crop and considered as one of the main legumes grown in Egypt. It considered as a good source of protein carbohydrate and other nutrients.

\footnotetext{
* Assoc. Prof., Agric. Eng., Dept., Faculty of Agric., Zagazig Univ. ** Prof., Agric. Eng., Dept., Faculty of Agric., Zagazig Univ.
} 
Mbagwu and Osuigwe (1985) found that the highest cowpea yield was obtained when irrigation with water equivalent to $100 \%$ field capacity every 2 days compared with 4 days. Arnaout (1995) showed that the average the irrigation efficiency, distribution uniformity, water saving and lima beans yield of the drip system increased by 15.87 and $38.37 \%, 8.87$ and $11.37 \%, 3.13$ and $96.99 \%$ and 27.49 and $12.95 \%$ compared with sprinkler and furrow systems, respectively. Shehata and Bakeer (1995) found that the drip irrigation system saving water applied by 48.25 and 96.78\% compared with sprinkler and furrow systems respectively, and showed that potatoes yield, water use efficiency and water benefit under drip, sprinkler and furrow systems were 9.43, 7.30 and 5.30 ton/fed, 2.07, 1.20 and $0.76 \mathrm{~kg} / \mathrm{m}^{3}$ and $1.033,0.601$ and $0.379 \mathrm{LE} / \mathrm{m}^{3}$ respectively. Shahien et al. (1996) found that increasing the irrigation number from 4 to 8 , the green cowpea yield, dry yield, pod length, pod weight, seed number per pod and 100-seed weight were increased from 3.13 to 3.53 ton/fed, 0.89 to 1.01 ton/fed, 12.57 to $13.34 \mathrm{~cm}, 3.45$ to $4.6 \mathrm{~g}, 8.77$ to 9.76 and 14.37 to $17.35 \mathrm{~g}$ respectively. Arnaout (1997) reported that the drip system saved about 13.05 and $26.61 \%$ of irrigation water requirements compared with sprinkler and furrow systems respectively and found that the highest pea yield values of 2.625, 2.35, 2.4 ton/fed were obtained under drip, sprinkler and furrow systems respectively. Arnaout (1999) found that the surface drip system increase the lima beans by 5.6 and $8.77 \%$ and decrease the cost of production unit by 6.8 and $10.2 \%$ than subsurface drip and sprinkler systems. Shawky et al. (2001) found that the application efficiencies were 92.9, 92.56, 81.48 and $65.7 \%$ for subsurface drip, surface drip, sprinkler and furrow systems, respectively. They also found that the surface and subsurface drip systems saved 22.2 and $21.7 \%$ of the irrigation water requirements comparing to sprinkler system and saved 51.55 and $50.90 \%$ when compared with furrow irrigation system, and the total green bean yield and water use efficiency for subsurface drip system increased by 29.44 and 27.64\%; 57.87 and $222.30 \%$ and 40.23 and $77.78 \%$ compared with surface drip, furrow and 
sprinkler systems. El-Gindy and Abdel-Aziz (2003) found that the drip irrigation system saved of water requirement, total maize yield and water use efficiency about 20.3, 20.76 and 40\% compared with sprinkler irrigation system. They also found that lowest cost of maize production unit was 64.6 LE/Mg under drip irrigation system when $100 \%$ of ETc daily was applied. Gencoglan et al. (2005) found that the averages of total applied water and the highest mean potential dry yield under basin, sprinkler and drip irrigation were 937.7 and 1.13, 913.4 and 1.36 and $886.5 \mathrm{~mm}$ and $1.58 \mathrm{t} / \mathrm{ha}$, respectively.Thus, the mean seasonal water use by pepper varied from 1020.7 to $1109.7 \mathrm{~mm}$. Hassanli et al. (2009) indicated that the maximum and minimum water saving, corn yield and WUE of 2471 and $1845.4 \mathrm{~m}^{3} / \mathrm{fed}, 5.07$ and 4.08 ton/fed and 2.12 and 1.43 $\mathrm{kg} / \mathrm{m}^{3}$ were obtained with subsurface drip and furrow method.

The objectives of this work were to determine the effect of irrigation systems on application efficiency, distribution uniformty, irrigation efficiency, cowpea yield, yield components, water use efficincy, water saving, cost per unit production and net profit in sandy soil conditions.

\section{MATERIALS AND METHODS}

The field experiments were carried out at El-Khattara experimental Farm, Faculty of Agriculture, Zagazig University, Sharkia Governorate during summer season 2009. The experimental was conducted to study the effect of irrigation systems on application efficiency, distribution uniformty, irrigation efficiency, cowpea yield, yield components, water use efficincy, water saving, cost per unit production and net profit in sandy soil conditions. Conventional analysis of the soil samples and irrigation water used were preformed and the results are tabulated in Tables (1 and 2).

Table (1): Some physical and chemical properties of the experimental site.

\begin{tabular}{|c|c|c|c|c|c|c|c|c|c|c|c|}
\hline \multirow{2}{*}{$\begin{array}{c}\text { Soil } \\
\text { depth } \\
(\mathbf{c m})\end{array}$} & \multicolumn{3}{|c|}{$\begin{array}{c}\text { Particle size } \\
\text { distribution }(\%)\end{array}$} & \multirow{2}{*}{ हृ } & \multirow{2}{*}{ 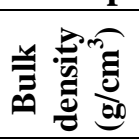 } & \multirow[t]{2}{*}{ 西 } & \multirow{2}{*}{ 记 } & \multirow{2}{*}{$\sum_{0}^{0} 0$} & \multirow{2}{*}{ 解 } & \multirow{2}{*}{ 㐘 } & \multirow{2}{*}{80} \\
\hline & Sand & Silt & Clay & & & & & & & & \\
\hline $0-20$ & & & & 2.4 & 1.35 & & 1.3 & & & 5.0 & 6.0 \\
\hline 20 & & & & & & & 1.2 & & 0 & 5.1 & 5.6 \\
\hline $40-60$ & 88.5 & 8.5 & 3.0 & 2.7 & 1.30 & 8.7 & 1.5 & 0.25 & 10.5 & 5.0 & 5.5 \\
\hline
\end{tabular}

- Field capacity (F.C) and wilting point (A.W.) by weight 
Table (2): Chemical analysis of irrigation water used.

\begin{tabular}{|c|c|c|c|c|c|c|c|c|c|c|c|c|}
\hline \multirow[b]{2}{*}{ th } & \multirow[b]{2}{*}{ 焉 } & \multicolumn{4}{|c|}{ Cations (meq/L) } & \multicolumn{4}{|c|}{ Anions (meq/L) } & \multirow[b]{2}{*}{$\frac{n}{4}$} & \multirow[b]{2}{*}{ 荾 } & \multirow[b]{2}{*}{ 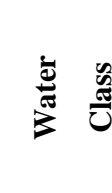 } \\
\hline & & $\underset{\mathbf{z}}{ \pm}$ & שٓ & ${ }^{+}{ }^{+}{ }_{\Sigma}$ & \pm & $\bar{\tau}$ & $\overbrace{0}^{\infty}$ & ช & 'ீ) & & & \\
\hline 7.5 & 1.76 & 10.2 & 6.4 & 4.6 & 0.8 & 9.7 & 6.4 & - & 6.3 & 4.35 & 4.88 & $\mathrm{C}_{2} \mathrm{~S}_{1}$ \\
\hline
\end{tabular}

Irrigation systems:

The used irrigation systems one the following:

- Sprinkler irrigation system consist of the following components: A control head (pumping station delivered flow rate of $120 \mathrm{~m}^{3} / \mathrm{h}$ under operating pressure of 5.0 bar, pressure manometers, regulate pressure, main pipe lines with PVC diameter of $12.5 \mathrm{~cm}$ buried at depth of $1.20 \mathrm{~m}$ under the ground, lateral pipe lines with $75 \mathrm{~mm}$ diameter of PVC, riser of $80 \mathrm{~cm}$ height, sprinkler nozzles with 3.6 and $2.4 \mathrm{~mm}$ diameter and the distance between sprinklers were 12 x $12 \mathrm{~m}$.

- Drip and subsurface irrigation systems consists of the following components: Control head (centerifugal pump, valves, manometer, pressure control valves, regulate pressure, screen filters with 200 mesh, fertilizer tank, main line pipe PVC underground with diameter of 75 $\mathrm{mm}$, submain lines flexible PVC pipes laid underground with $50 \mathrm{~mm}$ diameter, lateral line: surface lateral emitter lines polyethylene pipes have small diameter of $16 \mathrm{~mm}$ and subsurface lateral emitter lines (GR) polyethylene pipes have small diameter of $16 \mathrm{~mm}$ laid on the ground parallel to each other at $75 \mathrm{~cm}$ and dripper, fastened to the emitter liner with equal distances of $30 \mathrm{~cm}$ and flow rate of $4 \mathrm{lph}$. The lateral line each with $24 \mathrm{~m}$ length.

- Surface irrigation system consists of main and submain canals. The plots were irrigated by means of concrete pipe to deliver a given quantity of irrigation water through a gat valve constructed on the pipe to regulate the amount of water required to each plot.

All experimental unit received equal amounts of farmyard manure at rate of $20 \mathrm{~m}^{3} / \mathrm{fed}$. Nitrogen fertilizer in form of ammonium sulphate $(20.5 \%$ $\mathrm{N}$ ) was added at rate of $100 \mathrm{~kg} / \mathrm{fed}$ before sowing irrigation. Phosphorus fertilizer in form of calcium superphosphate $\left(15.5 \% \mathrm{P}_{2} \mathrm{O}_{5}\right)$ was applied during seeding preparation at rate of $200 \mathrm{~kg} / \mathrm{fed}$. Potassium fertilizer in 
from of potassium sulphate $\left(48 \% \mathrm{~K}_{2} \mathrm{O}\right)$ at rate of $50 \mathrm{~kg} / \mathrm{fed}$. The seed planting cowpea (Kream-7cvs) was done in the row in $1^{\text {th }}$ May 2009 at 30 $\mathrm{cm}$ apart. The first harvesting was carried at $11^{\text {th }}$ August 2009. The total net area of the experiment was $1512 \mathrm{~m}^{2}$. Sprinkler irrigation system had $\left(864 \mathrm{~m}^{2}\right)$, and the three other systems had $(648 \mathrm{~m})$ divided into three equal plots of $\left(216 \mathrm{~m}^{2}\right)$ for drip, subsurface and surface irrigation systems. Measurements and calculations:

\section{Irrigation system Efficiencies:}

a. Application efficiency (AE): Was calculated from the following equation according to Wu and Gitilin (1975)

$$
\mathrm{AE}=\frac{\mathrm{W}_{\mathrm{DZ}}}{\mathrm{D}_{\mathrm{T}}} \times 100
$$

Where:

$\mathrm{W}_{\mathrm{DZ}}$ : depth of water stored in the root zone, $\mathrm{cm}$.

$\mathrm{D}_{\mathrm{T}} \quad$ : gross depth of applied water.

b. Water distribution uniformity (DU): Was calculated from the following equation according to Merriam and Karmeli (1979)

$$
D U=\frac{D L q}{D a v}
$$

Where:

DLq: the depth infiltrated on the quarter of the area, which received the lowest amount of the irrigation water.

Dav: the average depth of infiltrated water.

c. Irrigation system efficiency $\left(\mathbf{E}_{\mathbf{s}}\right)$ : Was calculated from the flowing formula according to Wu and Gitilin (1975).

$$
\mathrm{E}_{\mathrm{s}}=\mathrm{AE} \times \mathrm{DU}
$$

\section{Irrigation water}

a. Amount of water added : Was calculated according to the following equation as sited from (Aboamera 2010): 


$$
\mathrm{IRa}=(\mathbf{F} . \mathrm{C}-\mathrm{M.B}) \times \boldsymbol{\rho} \times \mathbf{Z} \times \mathbf{A} / \mathbf{E}_{\mathrm{s}}
$$

Where:

IRa : Volume of water at each irrigation event, $\left(\mathrm{cm}^{3}\right)$

F.C : Soil moisture content at field capacity, (\%)

M.B : measured soil moisture content before irrigation, (\%)

$\boldsymbol{\rho}$ : soil bulk density $\left(\mathrm{g} / \mathrm{cm}^{3}\right), \quad \mathbf{Z}$ : depth of root zone $(\mathrm{cm})$,

A : irrigated area $\left(\mathrm{cm}^{2}\right)$, and $\mathbf{E}_{\mathbf{s}}$ : irrigation system efficiency (\%).

b. Calculated irrigation water requirements and crop coefficient:

The amount of calculated irrigation water requirements was determined by using Blany and Kriddle method, according to the following equation (Vermeiren and Jobling, 1980)

$$
\begin{aligned}
I R c & =\frac{\left\lfloor\left(E T_{\mathrm{O}} \times K c\right) \times D d\right\rfloor+L f}{E s} \\
\mathrm{Kc}_{\mathrm{FAO}} & =\frac{(\mathrm{Es} \times I R c)-L f}{\mathrm{ET}_{0} \times \mathrm{Dd}}
\end{aligned}
$$

Where:

IRc: calculated irrigation water requirements, $\mathrm{mm} /$ intervals.

$\mathrm{ET}_{\mathrm{o}}$ : evapotranspiration, $\mathrm{mm} / \mathrm{day}$.

kc : crop coefficient for (Doorenbos and Kassam,1979) .

Dd: time intervals. Es : system efficiency, \%.

$$
\mathrm{Kc}_{\text {calculated }}=\frac{(\mathrm{Es} \times I R a)-L f}{\mathrm{ET}_{0} \times \mathrm{Dd}}
$$

c. Potential evapotranspiration (ETo): Was calculated according to CROPWAT program. Agro-meteorological data were measured during the running of the experiment (Table 3 ). 
Table (3): Average Agro-meteorological data in month at EL-Khtara.

\begin{tabular}{||c|c|c|c|c|c|c|}
\hline Month & $\begin{array}{c}\text { Max Temp. } \\
\left(\mathbf{c}^{\circ}\right)\end{array}$ & $\begin{array}{c}\text { Min Temp. } \\
\left(\mathbf{c}^{\circ}\right)\end{array}$ & $\begin{array}{c}\text { Relative } \\
\text { Humidity } \\
(\boldsymbol{\%})\end{array}$ & $\begin{array}{c}\text { Wind speed } \\
(\mathbf{m} / \mathbf{s e c})\end{array}$ & $\begin{array}{c}\text { Sunshine } \\
(\mathbf{h})\end{array}$ & $\mathbf{E T}_{\mathbf{0}}$ \\
\hline May & 28.7 & 18.2 & 55.7 & 1.55 & 10.2 & 5 \\
\hline June & 35.7 & 22.1 & 58.7 & 1.47 & 11.8 & 5.6 \\
\hline July & 36.2 & 21.4 & 60.8 & 1.34 & 12.1 & 6.2 \\
\hline August & 36.0 & 19.8 & 45.7 & 1.36 & 11.5 & 5.7 \\
\hline
\end{tabular}

3. Total yield and its component: At harvesting time five plants from each treatment were randomly taken to determine pod length, dry pod mass, number of pods/plant, number of seeds/pod, seeds mass/pod, pod diameter, mass of 100 seeds, and total yield (pod and seed).

4. Water use efficiency: Was calculated according to Jensen (1983) as follows:

$$
\text { WUE }=\frac{\text { Total fresh yield }(\mathrm{kg} / \mathrm{fed})}{\text { Actual applied irrigation water }\left(\mathrm{m}^{3} / \mathrm{fed}\right)}, \mathrm{kg} / \mathrm{m}^{3} \ldots .(7)
$$

5. Water saving: Was calculated by the follows formula:

$$
\text { Water saving }\left(\mathrm{m}^{3} / \mathrm{fed}\right)=M I R a-\mathrm{IRa} \mathrm{T}
$$

Where:

$M I R a:$ maximum actual irrigation water requirement at treatment, $\left(\mathrm{cm}^{3}\right)$

$I R a T$ : actual irrigation water requirement at treatment, $\left(\mathrm{cm}^{3}\right)$

\section{Cost analysis}

Cost analysis was carried out by using the current dealer prices for equipment and installation according to 2012 price level and cowpea production cost.

\section{Total cost:}

a- Irrigation system costs: Capital irrigation system cost was calculated using the current dealer prices for equipment and installation according to 
2012 price level. The following cost analysis evaluation has been carried out according to Worth and Xin (1983).

1) Fixed costs: The annual fixed cost of capital investment in the irrigation system was calculated using the following equation:

$$
\mathbf{F} . \mathbf{C}=\mathbf{D}+\mathbf{I}+\mathbf{T}
$$

Where:

F.C : annual fixed cost (LE/year), D : depreciation (LE/year),

I : interest (LE/year) and $\quad \mathbf{T}$ : taxes and overhead ratio (LE/year).

Depreciation: Depreciation of the components of an irrigation system is based on the expected life of each element. The expected life of a number of irrigation system components has been prepared from numerous sources as guidelines and saved for estimating depreciation. Depreciation was calculated according to (Jensen 1981) using the following equation:

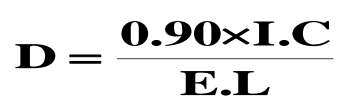

Where:

I.C : is the element initial cost of irrigation system (LE) and

E.L: the element expected life (year).

Capital interest: was calculated using the following equation:

$$
\mathbf{I}=\frac{\mathbf{I} . \mathbf{C} \times \mathbf{1 . 1 0}}{\mathbf{2}} \times \mathbf{I . R}
$$

Where:

I.R : is the interest rate/year.

Taxes and overheads ratio: The annual cost of taxes can be obtained from the taxing entity in the particular location where the irrigation development is occurring. Insurance costs obtained similarly from insurance companies. The combined cost for taxes and insurance normally runs in the range of 1.5 to $2.5 \%$ of the initial investment value of the irrigation facilities (Jensen 1981). Taxes and insurance were considered to be $2.0 \%$ from initial cost. 
2) Running cost: The annual running cost of capital investment in the irrigation system was calculated using the following equation:

$$
\mathbf{R C}=\mathbf{E} \cdot \mathbf{C}+(\mathbf{R} \& \mathbf{M})+\mathbf{L} \cdot \mathbf{C}
$$

Where:

RC: annual running costs (LE/year), L.C: labor costs (LE/year),

E.C: energy costs (LE/year) and

(R\&M): repairs and maintenance costs (LE/year).

Labor cost: Labor to operate the system cost and to check the system components depends on irrigation operating time. This time would change from system to another according to irrigation water application rate. Labor cost was estimated as follows:

$$
\mathbf{L . C}=\mathbf{T} \times \mathbf{N} \times \mathbf{p}
$$

Where:

L.C: annual labor cost (LE/year), T : annual irrigation time (T/year),

$\mathbf{N}$ : labor number/feddan and $\mathbf{P}$ : labor cost $(\mathrm{LE} / \mathrm{h})$.

Energy cost: The energy cost for electrical type source was calculated using the following formula:

$$
\text { E.C }=\mathbf{B p} \times \mathbf{T} \times \mathbf{p r}
$$

Where:

E.C : energy costs for electricity (LE/year),

Bp : the brake power $(\mathrm{kW}), \quad \mathbf{T} \quad$ : the annual operating time (h) and

Pr :cost of electrical power (LE/kW.h).

The brake horse power required $(\mathbf{B p})$ in $\mathrm{kW}$ for water pumping was calculated by using the following equation (Longenbaugh and Duke,1981):

$$
\mathbf{B}_{\mathbf{p}}=\frac{\mathbf{Q} \times \mathbf{T}_{\mathbf{D H}}}{\mathbf{C} \times \mathbf{E}_{\text {overall }}}
$$

Where: 

Q : total discharge rate (1/s), $\quad \mathbf{T}_{\mathbf{D H}}$ : total dynamic head (m),
C: conversion coefficient to energy unit, 102 according to Jensen 1981,
$\mathbf{E}_{\text {overall: overall efficiency (67.5\% for pump derived by electric motor) }}$

Repairs and maintenance costs: The annual cost of repairs and maintenance of irrigation system were taken as $2-3 \%$ of the initial cost.

Total annual irrigation costs $=$ fixed costs + running costs

b- Fertilization cost: Were calculated as following:

$$
\mathbf{F r}=(\mathbf{W f} \times \mathbf{p r})+\mathrm{Ac}
$$

Where:

Fr : fertilization costs (LE/fed), Wf : amount of fertilizers $(\mathrm{kg} / \mathrm{fed})$,

Pr: fertilizer price (LE/kg) and Ac: application fertilizer costs (LE/fed).

c- Weed control costs: Was carried out manually by using labors and weed control cost was calculated as following:

$$
\mathbf{W c}=\mathbf{N} \times \mathbf{L} \times \mathbf{T}
$$

Where:

Wc : weed control costs (LE/fed), $\mathbf{N}$ : labors number/feddan,
L : labor cost (LE/h) and $\mathbf{T}:$ time used (h/fed).

d- Pest control cost: Was carried out by using the sprayer and pest control costs was calculated as following:

$$
\mathbf{P c}=(\mathbf{W p} \times \mathbf{p})+A \mathbf{c}
$$

Where:

Pc : pest control costs, LE/fed Wp : amount pesticide used, $\mathrm{kg} / \mathrm{fed}$, $\mathbf{P}$ : pesticide price, $\mathrm{LE} / \mathrm{kg}$ and

Ac : application pesticide costs LE/fed (sprayer rent and labor cost).

7. Cost per unit production: Was calculated by using the following formula: 


$$
\text { Cost per unit production }=\frac{\text { Total production costs }(\mathrm{LE} / \mathrm{fed})}{\text { Total fresh yield }(\mathrm{Mg} / \mathrm{fed})} \quad \mathrm{LE} / \mathrm{Mg} \text {.. (19) }
$$

8. Net profit: The economical net profit of cowpea yield was calculated by using the following formula (Younis et al.,1991):

$$
\mathbf{P}=(\mathbf{Y t} \times \mathbf{d})-\mathbf{C t}
$$

Where:

$\mathbf{P}$ : net profit, LE/fed; $\quad$ Yt : total yield, ton/fed;

D : yield price, LE/ton, and, $\mathbf{C t}$ : total production costs, LE/fed.

\section{RESULTS AND DISCUSSION}

\section{Irrigation systems Efficiency.}

The data presented in Fig. (1) shows that for subsurface irrigation, the application efficiency; distribution uniformity and total irrigation efficiency increased by $4.2,13.5$ and $60.1 \%$; 4.57, 15.97 and $29.06 \%$ and $8.99,31.70$ and $106.75 \%$ compared with drip, sprinkler and traditional irrigation systems. Generally, the values of application efficiency, distribution uniformity and irrigation efficiency obtained by both the subsurface and drip irrigation systems were much higher than sprinkler and traditional systems.

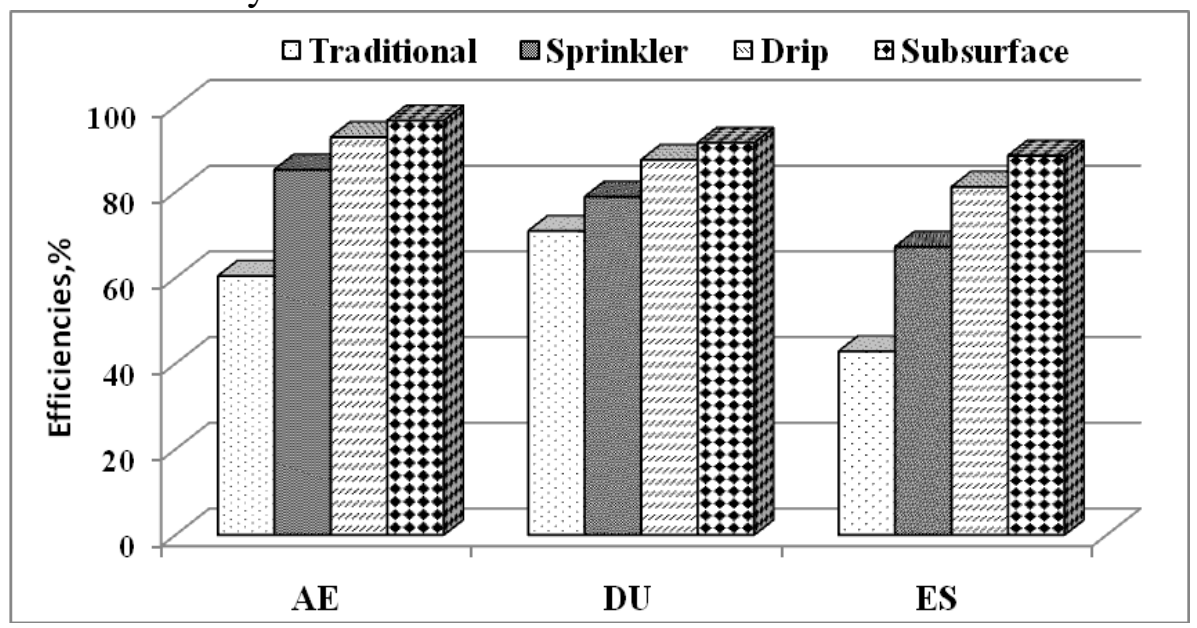

Fig. (1): Application efficiency, distribution uniformity and irrigation system efficiency under different irrigation systems. 


\section{Irrigation water}

a. Actual irrigation water applied.

The actual irrigation water applied for cowpea throughout growing season under traditional, sprinkler, drip and subsurface irrigation systems is given in Fig. (2). The obtained data revealed that the higher actual irrigation of water applied were found under traditional and sprinkler irrigation systems, while the lowest values was found under subsurface and drip irrigation systems, because the subsurface and drip irrigation systems have higher application efficiency compared with traditional and sprinkler systems. The actual irrigation of water applied were 3750, 2930, 2075 and $1970 \mathrm{~m}^{3} / \mathrm{fed}$ with using traditional, sprinkler, drip and subsurface irrigation systems, respectively.

\section{b. Calculated amount of irrigation water.}

The calculated irrigation water applied for cowpea throughout growing season under traditional, sprinkler, drip and subsurface irrigation systems are given in Fig. (2). The calculated amount of irrigation water with subsurface irrigation system was $2520 \mathrm{~m}^{3} / \mathrm{fed}$, but under traditional, sprinkler and drip were 4800, 2980 and $2653 \mathrm{~m}^{3} /$ fed.

The actual irrigation requirements lower than the calculated irrigation requirements, because we used the Kc from FAO under different conditions of climate and soil.

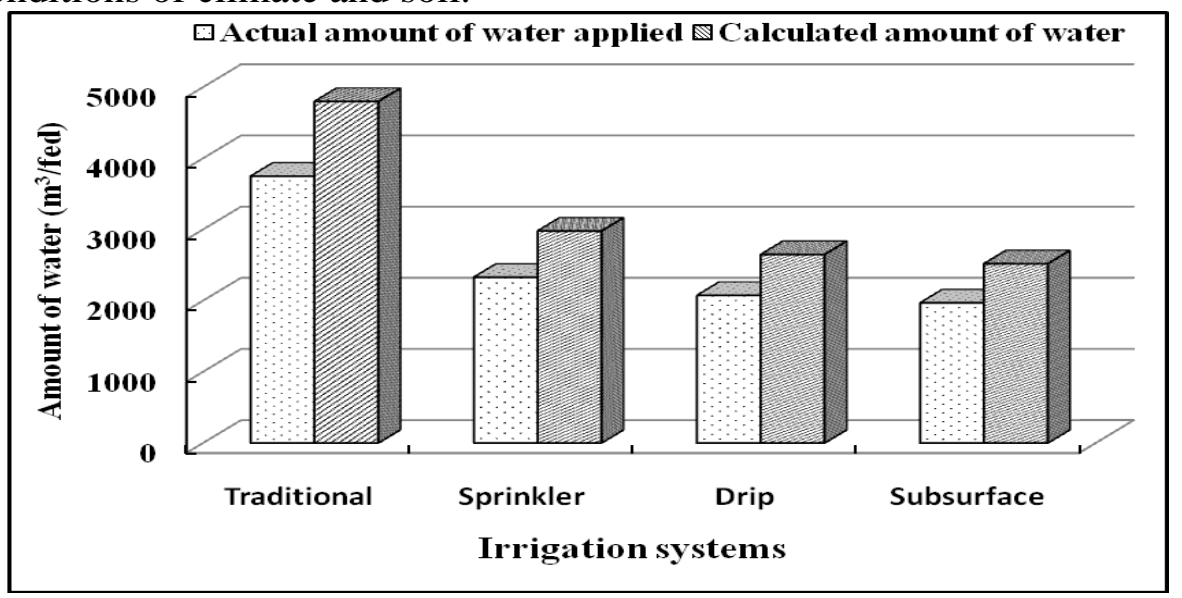

Fig. (2): Actual applied and calculated amount of irrigation water under different irrigation systems. 


\section{c. Kc calculated.}

The crop coefficient reflects the crop cover percentage and soil conditions on the ETo values. The Kc values were estimated from the delaying IRa rates and the delaying ETo rates. The results reveal that the Kc values, as a function of the interaction between IRa and ETo (as overall mean) were low during initial stage, then increased during development stage and reached its maximum values during Mid-season stage, thereafter, the Kc values redecreased again during late stage. Fig. (3) showed that crop coefficient values were $0.40,0.82,0.82$ and 0.55 ( $\left.\mathrm{Kc}_{\text {calculated }}\right)$ and 0.41 , 1.05. 1.05 and $0.60\left(\mathrm{Kc}_{\mathrm{FAO}}\right)$ at the different stage of cowpea under irrigation systems.

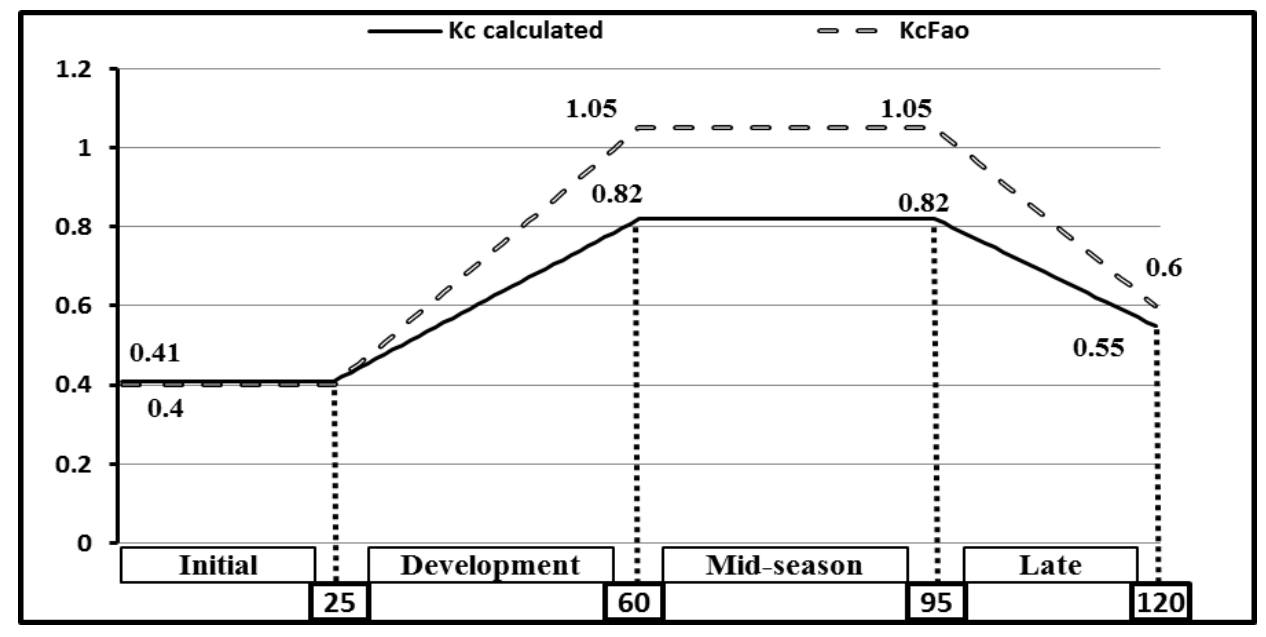

Fig. (3): The crop coefficient values of cowpea.

\section{Crop yield}

The data presented in Fig. (4) shows that for drip irrigation system increased the pod length, seed number per pod, pod number per plant, pod yield and seed yield by $10.27,12.51$ and $18.76 \%, 6.75,11.57$ and $14.61 \%, 19.21,41.17$ and $52.41 \%, 14.98,40.42$ and $61.76 \%$ and 6.91 , 28.34 and $45.0 \%$ compared with subsurface, sprinkler and traditional irrigation systems respectively. Generally, the results show that the highest yield and yield components were found by using drip irrigation compared with different irrigation systems. 


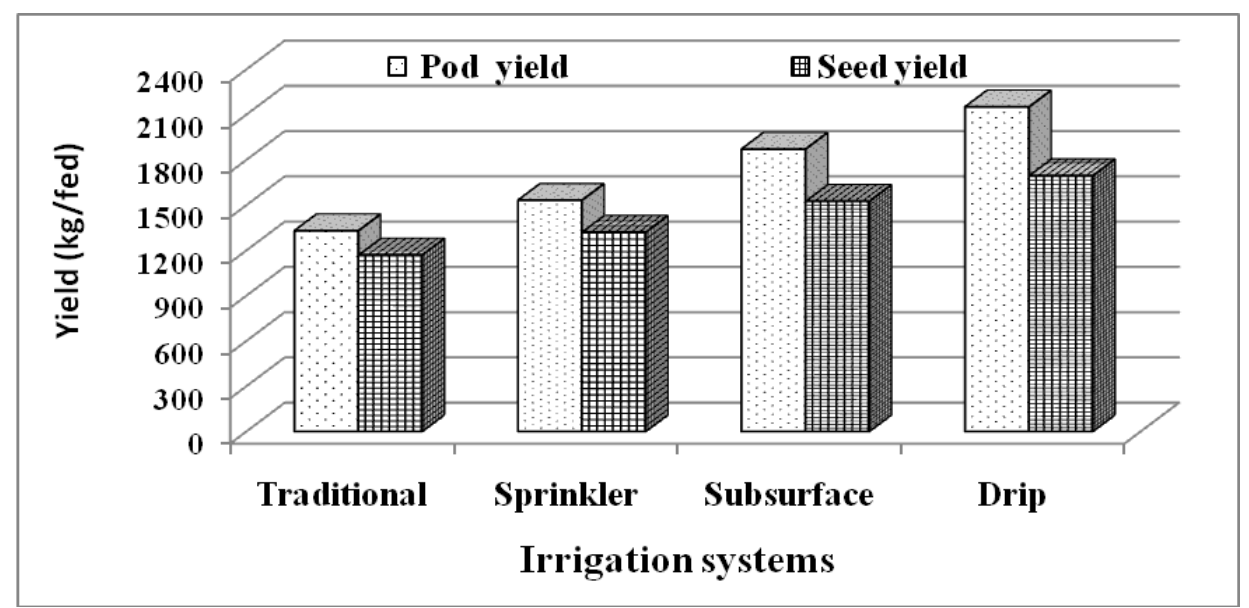

(4): The cowpea yield (pod and seed) under different irrigation systems.

\section{Water use efficiency (WUE)}

The data presented in Fig. (5) shows that the values of WUE for pod yield were $1.04,0.95,0.66$ and $0.36 \mathrm{~kg} / \mathrm{m}^{3}$ under drip, subsurface, sprinkler and traditional irrigation systems respectively. The data presented in Fig. (5) shows that the WUE values of pod and seed yield for drip irrigation was higher than both systems of subsurface (9.47 and 2.5\%), sprinkler (57.58 and $43.86 \%)$ and traditional (188.89 and $164.52 \%)$. This is attributed to the few water losses during the irrigation operating.

Finally, the obtained results revealed that, the highest value of WUE for pod and seed yield and minimum irrigation water applied was found by using subsurface irrigation and drip irrigation system.

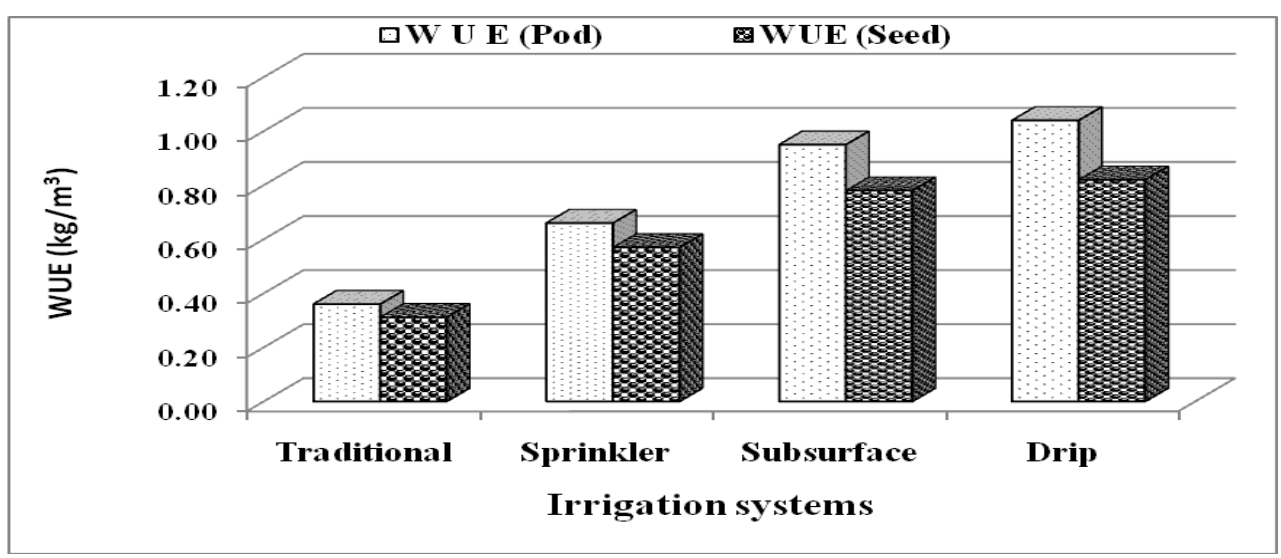

Fig. (5): Water use efficiency under different irrigation systems. 


\section{Water saving}

The water saving for cowpea throughout the growing season under different irrigation systems for the investigated is given in Fig. (6). The data showed that the water saving under the different treatments compared with the actual irrigation water requirements $3750 \mathrm{~m}^{3} / \mathrm{fed}$ ( Traditional). Results show that the highest value of water saving was obtained under subsurface $\left(1780 \mathrm{~m}^{3} / \mathrm{fed}\right)$, drip $\left(1675 \mathrm{~m}^{3} / \mathrm{fed}\right)$ and sprinkler $\left(1420 \mathrm{~m}^{3} / \mathrm{fed}\right)$ compared with traditional irrigation system. Generally, the results show that, the highest water saving was found with using subsurface and drip irrigation systems.

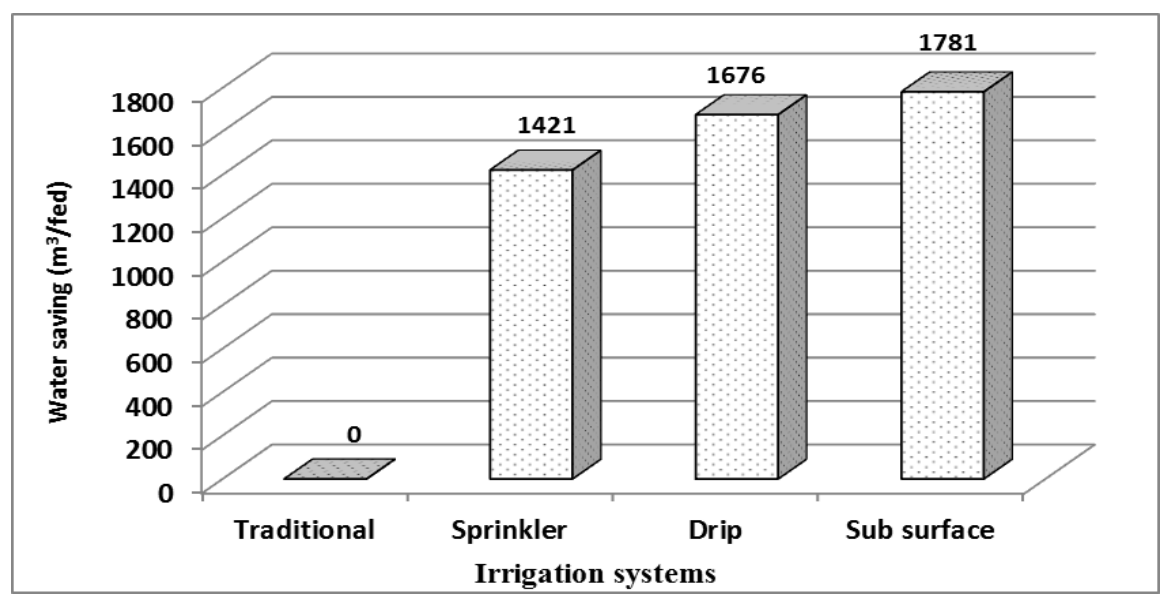

Fig. (6): Water saving of cowpea under different irrigation systems.

\section{Cost calculation.}

The results showed that the lowest cost per unit production (pod and seed) and highest net profit was found with using subsurface irrigation system. The results in Fig. (7) showed that the total cost of sprinkler irrigation (2225 LE/fed) higher than subsurface (2098 LE/fed), drip (1995 LE/fed) and traditional irrigation systems (1500 LE/fed). The cost per unit production (pod and seed) was 1128 and 1284, 1453 and 1686, 1122 and 1324 and 928 and $1178 \mathrm{LE} / \mathrm{Mg}$ under traditional, sprinkler, subsurface and drip irrigation systems. It could be concluded that the higher net profit was $3276 \mathrm{LE} /$ fed with drip irrigation system, $2680 \mathrm{LE} / \mathrm{fed}$ with 
subsurface, $1823 \mathrm{LE} /$ fed with traditional and $1602 \mathrm{LE} /$ fed with sprinkler irrigation systems.

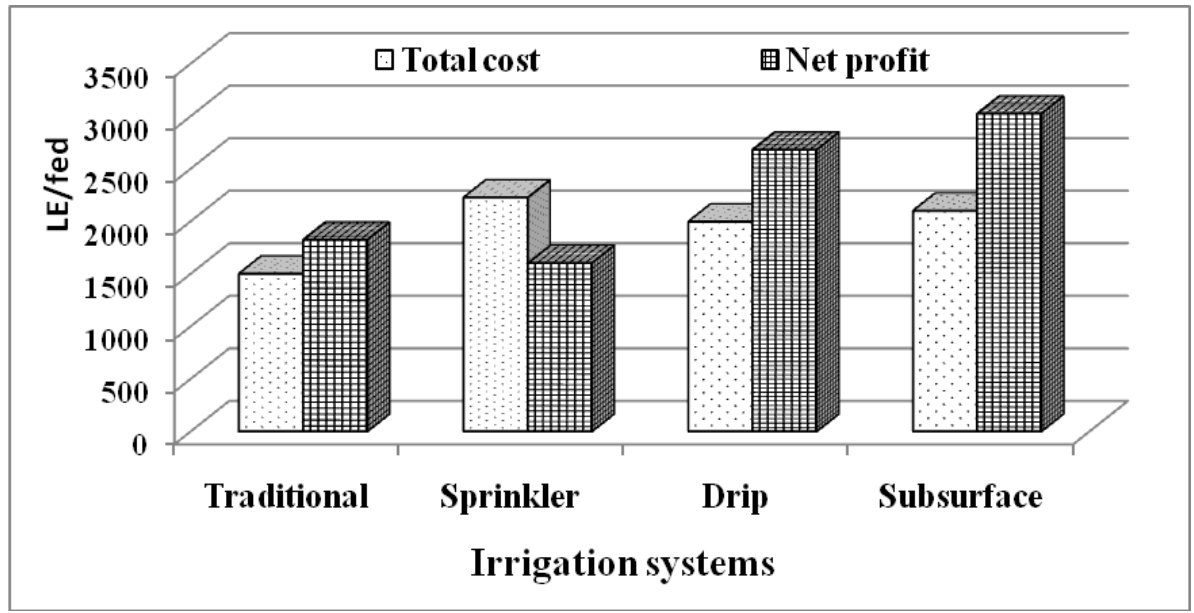

Fig. (7): Total cost, cost per unit production and net profit under different irrigation systems.

\section{CONCLUSIONS}

\section{The obtained results can be summarized as follows:}

1. The values of application efficiency, distribution uniformity and irrigation efficiency obtained by both the subsurface and drip irrigation systems were much higher than sprinkler and traditional irrigations.

2. The Kc values as a function of the interaction between IRa and ETo (as overall mean) were low during initial stage, then increased during development stage and reached its maximum values during Midseason stage, thereafter, the Kc values redecreased again during late stage.

3. The highest yield and yield components were found by using drip compared with different irrigation systems.

4. The highest value of WUE for pod and seed yield was found by using drip and subsurface irrigation systems. 
5. The highest water saving was found with using subsurface and drip irrigation systems.

6. The lowest cost per unit production (pod and seed) and highest net profit was found with using drip irrigation system.

\section{REFERENCES}

Aboamera, M.A.(2010). Response of cowpea to water deficit under semi-portable sprinkler irrigation system. Misr J. Ag. Eng., 27 (1): 170- 190.

Arnaout, M. A. I. (1995). A comparative study between some irrigation systems. Misr J. Agric. Eng., 12 (1): 46-54.

Arnaout, M. A. I. (1997). A study on selecting the proper applied water under different irrigation systems. Misr J. Agric. Eng., 14 (3): 310318.

Arnaout, M. A. I. (1999). A comparative study between fertigation and conventional methods of fertilizer application through different irrigation systems. Misr J. Agric. Eng., 16 (2):209-217.

Doorenbos, J. and A. H. Kassam (1979). Yield response to water. FAO Irrigation and Drainage Paper No. 33, Rome.

El-Gindy, A. M. and A. A. Abdel-Aziz (2003). Maximizing water use efficiency of maize crop in sandy soils. Arab Univ. J. Agric. Sci., Ain Shams Univ., Cairo, 11 (1): 439-452.

Gencoglan, C., S. I.E. Akinci; S. Akinci; K. Gencoglan and Ucan (2005). Effect of different irrigation methods on yield of red hot pepper and plant mortality caused by Phytophthora capsici Leon.J Environ Biol, 26(4):741-6.

Hassanli, A.M.; M. A. Ebrahimizadeh and S. Beecham (2009). The effect of irrigation methods with effluent and irrigation scheduling on water use efficiency and corn yields in an arid region. Agric. 
Water Management, 96 (1): 93-99.

Jensen, M. E. (1981). Design and operation of farm irrigation systems. ASAE Monograph (3) in a series pub. By ASAE,: 829 p.

Jensen, M.E. (1983). Design and operation of farm irrigation systems. ASAE, Michigan, USA., 827 p.

Longenbaugh, R. A. and H. R. Duke (1981). Farm pumps. In: Jensen, M.(Ed.). Design and operation of farm irrigation systems. ASAE Monograph No.3. St. Joseph. MI., USA 829 p.

Mbagwu, J. S. C. and J. O. Osuigwe (1985). Effect of varying levels and frequencies of irrigation on growth yield, nutrient uptake and water use efficiency of maize and cowpea in a sandy loam ultisol. Plant and soil 84, : 181-192.

Merriam, J.L. and J. Keller (1979). Irrigation System Evaluation: A Guide for Management. $3^{\text {rd }}$ ed. Published by Agricultural and Irrigation Engineering Department, Utah State University, Logan, Utah. 271 p.

Shahien, A. H. ; A. A. Abdel-Aziz and A. H. Kheraba (1996). Effect of cultivars, irrigation and intercropping system on yield and its components, pod characters and net return of cowpea. Zagazig J. Agric. Res., 23 (4): 571-590.

Shawky, M. E.; F. A. Gomaa; G. A. Bakeer and A. S. Mostafa (2001). Actual and calculated irrigation water requirement of green bean crop under different irrigation systems in Egypt. Misr J. Agric. Eng., 18 (3): 511-526.

Shehata, S. A. and G. A. Bakeer (1995). Effect of irrigation methods and nitrogen levels on potatoes in sandy soil. The Role of Agric. Eng. in Sustainable development, $3^{\text {rd }}$ Conf., Misr Soc. of Agric. Eng., 5-6 Oct.: 37-48. 
Vermeiren and Jobling (1980). Localized Irrigation. Irrigation \& Drainage Paper No. 36, FAO, Rome.

Worth, B. and J. Xin (1983). Farm mechanization for profit. Granada publishing, London, U. K. 269 p.

Wu, I.P. and H.M. Gitilin (1975). Irrigation efficiency of surface, sprinkler and drip irrigation. Reprinted from Proceeding second World Congress International Water Resources Association, New Delhi, 1: 191-199.

Younis, S. M.; M. A. Shiboon and A. O. Aref (1991). Evaluation of some mechanical methods of rice production in Egypt. Misr J. Agric. Eng., 8 (1): 39 - 49.

الملخص العربى

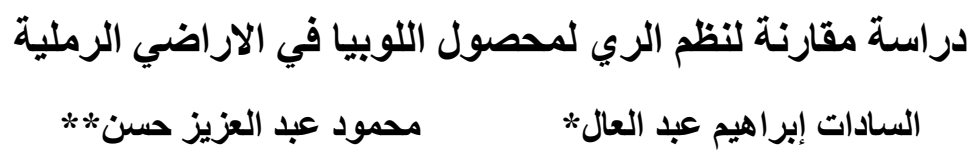

نظر المحدودية الموارد المائية والاستخدام الجائر للمياه في الار اضي الجديدة وقلة احتفاظها بها وزيادة عدد السكان، و الذي أدى الى تناقص نصيب الفرد من المياه، لذا كان من الضروري العمل العل علي ترشيد المياه المتاحه و المحافظة عليها وزيادة المساحه المرويه. ويعتبر تطبيق تقنيات الري الحديث أحد السبل الهامة في هذا المجال. وتقوم الفكرة الأساسية في هذا البحث على دراسة مقارنة لنظم الري المختلفة (الري السطحي و الري بالرش و الري بالتنقيط و الري تحت السطحي) علي انتظامية توزيع المياه وكفاءة النظام وترشيد المياه المستخدمة وانتاجية المحصول اللوبيا

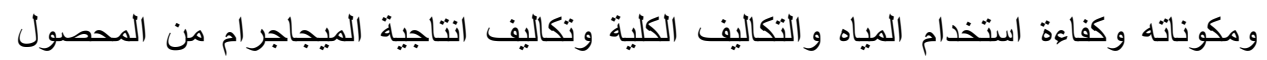
(القرون و البذور (وصافي الربح لمحصول اللوبيا في الار اضي الجديدة بمنطقة الخطارة محافظة

وكاتت أهم النتائج المتحصل عليها هي: • زيادة كفاءة الاضافة وانتظامية التوزيع وكفاءة الري تحت نظام الري تحت السطحي بالمقارنة بنظم الري الأخري (التنقيط ـ الرش ـ التقليدي).

* استاذ الهندسة الزراعية المساعد ـ قسم الهندسة الزراعية ـ كلية الزراعة - جامعة الزقازيق. ** استاذ الهندسة الزراعيةـ قسم الهندة الزراعية ـ كلية الزراعة ـ جامعة الزقازيق. 


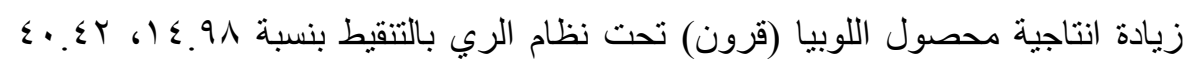

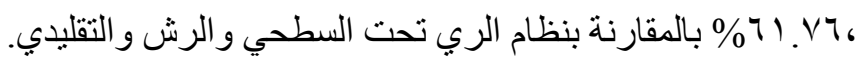

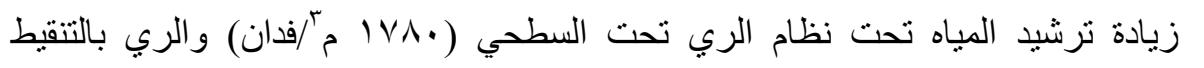

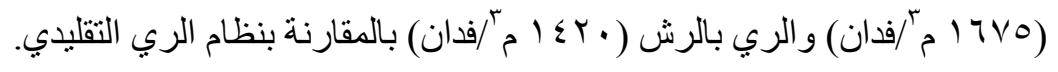

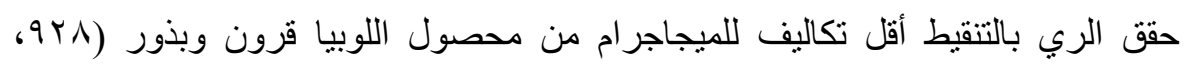

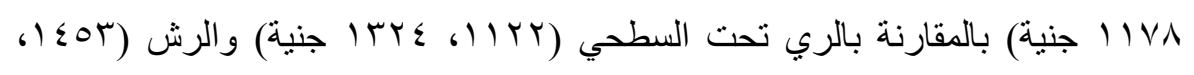

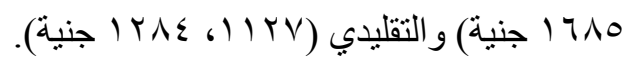

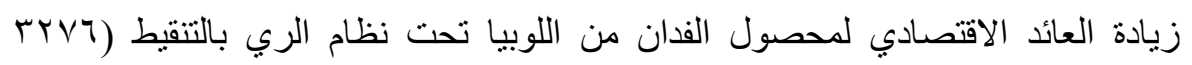

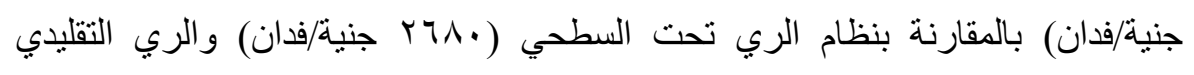

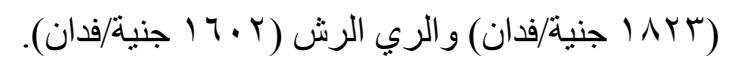

لذللك توصي الدر اسة عند زر اعة اللوبيا في الار اضي الجديدة يفضل استخدام نظام الري بالتتقيط

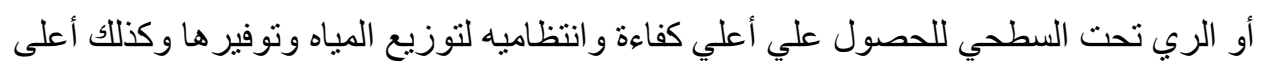

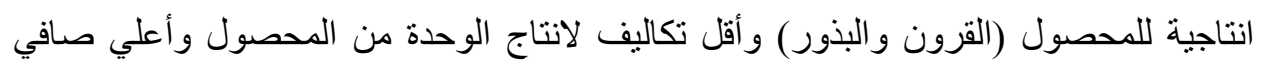
ربح في منطقة الدر اسة. 